\title{
"A Lesson on a Tortoise" and D. H. Lawrence's Earliest Crisis of Social Identity
}

\author{
Juan Camilo Conde Silvestre \\ Universidad de Murcia
}

\begin{abstract}
The short story "A Lesson on a Tortoise," written by D. H. Lawrence in 1909, has traditionally been disregarded by criticism as a very minor piece of work. This paper aims to show that the story has a threefold importance: firstly as an autobiographical portrait of Lawrence's activities as a teacher in Croydon; secondly as an example of Lawrence's ability to use realistic techniques; and thirdly as a reflection of the author's crisis of social identity. The paper concentrates on the last aspect and traces the personal and intellectual facets which came to shape Lawrence's ideas on the subject.
\end{abstract}

In December 1909 D. H. Lawrence finished "A Lesson on a Tortoise": a short story which aimed to reflect his tasks as a teacher at Davidson Road primary school, in the London suburb of Croydon. ${ }^{1}$ The contemporary criticism of the story is divided between the authors who see in it a certain barrenness during the first stages of Lawrence's career as a writer (Pinion 221), and those who appraise his prowess in handling realistic techniques, due to a zeal to give the reader a true report of the everyday life at the school (Hobsbaum 25-26). The story belongs to the group comprised under the heading "Croydon stories," written between 1908 and 1912: a period when Lawrence's writings were determined by Ford Madox Hueffer (Ford) and the English Review of Short Stories. The aims of this publication and of the "New Young School of Realism" which it promoted, were to shake off the influence of the nineteenth century tradition and to advance the composition of prose as sophisticated as it already existed in the continent. The means to achieve these resolutions was to concentrate themes on the everyday life of British people (Hueffer 1-16; Cushman 102), so that in "A Lesson on a Tortoise" Lawrence turns to his experience and gift of observation to bring the reader face to face with the behaviour of two different groups of pupils when they see the tortoise-a strange creature in their usual environment.

Harris has summarized the main realistic features of these stories: (a) they are built around a limited number of scenes and symbols, due to a structural economy imposed by 
the genre which results in the use of polysemic imagery; the main symbol of "A Lesson on a Tortoise" is the animal, whose secondary function is to foreground the different behaviour of the two groups of students; (b) the narrator has a clear preference for the showing rather than the telling mode and therefore makes the role of mimetic techniques-scene and dialogue-prevail over the diegetic ones-summary and description; (c) the priority of mimesis over diegesis allows his characters to present themselves, so that the narrator's voice mingles with those of a wide variety of human perspectives, and even his register overlaps with the characters' in an innovative way which had only appeared before in works by Eliot and Hardy (Harris 26-27).

"A Lesson on a Tortoise" can also be regarded as an autobiographical confession of the interests and strains which Lawrence had to confront during his period as a teacher. A comparison between Lawrence's own words and the structure of the story can certainly confirm the issue: the title, for instance, gives a clue to the enjoyment the author found during the lessons devoted to natural sciences and drawing; the plot reflects both the pedagogical innovations attempted by Lawrence and the problems which he encountered in his job; the annoyance of an unrewarding and tiring task and the contradictions between discipline and freedom in the educational process clearly underlie the following words: "School is a conflict-mean and miserable-and I hate conflicts ... the lads and I have a fight, and I have a fight with my nature, and I am always vanquished . . I struggle with my nature and with my class, till I feel all frayed into rags" (Letters 1: 85). A similar tone of dissatisfaction and concern for renovation appears in the poems of the Schoolmaster Series, and were confirmed to Lawrence's biographer E. Nehls by Philip F. T. Smith, the headmaster of "Davidson Road School," and A. W. McLeod, one of his work mates."

However, a contextual reading of "A Lesson on a Tortoise" places the text in a dimension beyond the autobiographical portrait or an exercise in the handling of realistic techniques. The author's attitude towards the life surrounding him, summarized by Young with the aphorism "nihil humanum mihi alienum est" (15), is mixed up in this case with his capacity as "social historian" (Leavis 145) and his "power to translate the raw material of everyday life into a meaningful form" which J. Chambers would apply to him (192). The result is a portrait of the social reality of Croydon which, at the same time, works as a symbolic microcosm of these circumstances in Great Britain as they are shaped by Lawrence's own experience and attitude to the subject.

The story starts by placing the reader spatially and temporally: it is the last lesson of the week, on Friday afternoon, and the teacher is conscious of how tiring activities usually are that day; so he decides to combine a lesson on natural sciences with the motivating drawing of a live animal: the tortoise. After these spatial details the narrator describes in the first person a quite heterogeneous group of students:

They were a small class of about thirty-my own boys. A difficult mixed class, they were, consisting of six Gordon Home boys, five boys from a fairly well-to-do Home for the children of Actors, and a set of commoners varying from poor lads who hobbled to school, crippled by broken enormous boots. The Gordons were a difficult set; you could pick them out: crop haired, coarsely dressed lads, distrustful, always ready to assume the defensive. They would lie till it made my heart sick if they were charged with offence, 
but they were willing and would respond beautifully to an appeal. The actors were of a different fibre: some gentle, a pleasure even to look at; others polite and obedient, but indifferent, covertly insolent and vulgar; all of them more or less gentlemanly. (16-17)

The first pupils to be introduced are the boys from the "Gordon Home": an institution for orphans established in Croydon in 1903 by the "Church of England Society for Providing Homes for Waifs and Strays," which was, at the time, run by charity. In the year 1908-1909 there were actually eight students from that orphanage in Lawrence's class, and even the attitude of the narrator coincides with the author's who stated in a letter to May Holbrook, written in December 1908: "They are of insolent, resentful disposition ... they make me jolly mad, but I am sorry for them" (Collected Letters 97 ). ${ }^{3}$ The references to the boys from a middle-class institution for orphans, illegitimate and unwanted children of actors and actresses-“The Actors' Orphanage Fund"-helps to establish the social mixture which characterizes the group. The narrator's viewpoint also coincides with the author's who, in the course of the above mentioned letter, wrote the following words about the six students from the actors' orphanage which he actually had in his class: "They are delightful boys, refined, manly and amiable" (Collected Letters 97). The narrator, however, does not seem to have preconceived preferences for any of the groups: he rejects the defensive and distrustful attitude of the former but also esteems their good disposition in case they are needed. At the same time, he values positively the outward appearance and the education of the latter, but rejects their indifference and superiority.

The development of the story is certainly poor and may support the ideas of Pinion considered in the opening section of this paper. When the teacher is distributing rubbers among the students he notices that some of them have been stolen; his first reaction is to accuse the lower-class boys, the orphans of the "Gordon Home," in a paragraph which may reflect a real life situation and the problems Lawrence had to face in order to keep discipline in his class:

"Marples!," I cried to one of them, "where are those rubbers?"

"I don't know where they are:-I've never 'ad no rubbers'-he almost shouted back, with the usual insolence of this set. I was more angry. ...

"Come here!," I cried, "come here! Fetch the cane, Burton. We'll make an end, insolence and thieving and all...."

"Now my lad!," I said, "I'll cane you for impudence first. ..."

"Well," he shouted to me, "you always pick on the Gordons-you're always on to us- - !..."

"Why," I exclaimed, "what a disgraceful untruth! I am always excusing you, letting you off-?"

"But you pick on us-you start on us-you pick on Marples, an' Rawson, an' on me. You always begin with the Gordons."

"Well," I answered, justifying myself. "Isn't it natural? Haven't your boys stolen-haven't these boys stolen-several times-and been caught?"

"That doesn't say as we do now." (18-19)

When the discussion does not seem to come to an end, the teacher asks the students to write down on a piece of paper the name of the classmate who they think is responsible 
for the theft. Most of them accuse Segar, the narrator's monitor, who belongs to the middle class and lives in the "Actor's Orphanage":

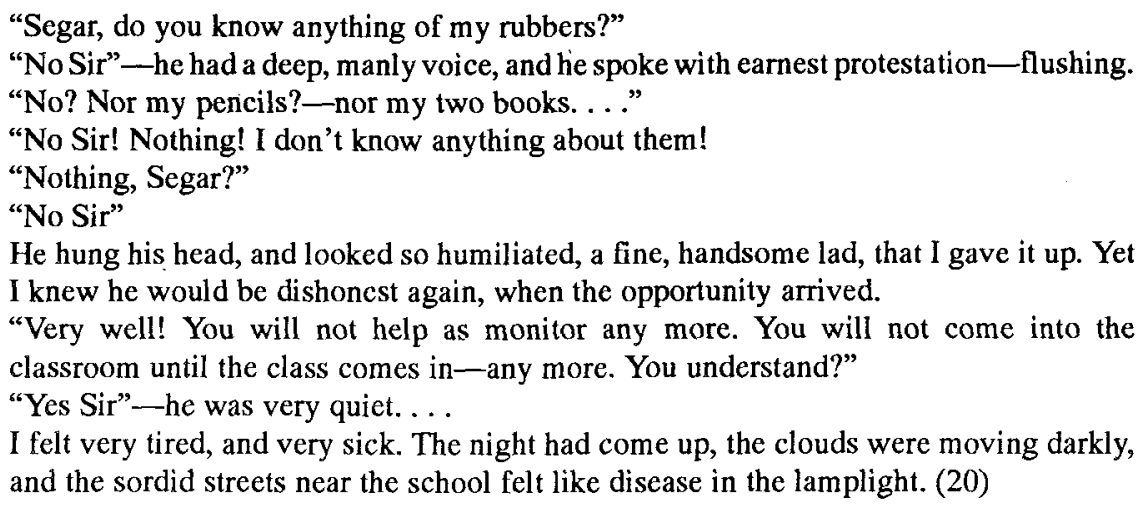

A comparison between both paragraphs may link the ideas mentioned so far since the realistic techniques used in them help to corroborate the social characterization of each group of pupils. The "Gordon" boys are made to use substandard and dialectal features of a morphosyntactical and phono-graphological nature: as works as a connective in relative clauses, never as a negative particle; the phoneme/grapheme $/ \mathrm{h}-/$ is generally dropped in initial position, and the last consonant of the conjunction $a n^{\prime}$ is apocopated. In contrast, Segar's literary idiolect does not show any substandard feature in connection with his attachment to the middle classes. The sociolect ascribed to each character works therefore in relation to the social differences which the story wants to highlight, so that this stylistic feature supports the thematic development. At the same time, this mimetic, realistic technique may contribute to the apparent neutrality of the narrator when he has to face the behaviour of the two groups of socially different characters. However, a deeper comparison of the two paragraphs suggests that the final attitude of the narrator is not so neutral; the weariness and feebleness he shows in the last lines of the quotation may be due both to the accumulated activities of the working week and to the psychological strain caused by the behaviour of the students: the teacher realizes that the vulgarity and closed mentality of both social groups is incurable, and his value system is highly unbalanced. I think, therefore, that "A Lesson on a Tortoise" must also be studied as a symbolic microcosm of the British social reality of the time it was written, and, so far as it reflects personal and intellectual circumstances of its author's life, as a safety-valve for the crisis of social identity which Lawrence was starting to suffer.

The reasons for Lawrence's problems of social identification can be traced both through his biographical circumstances and the intellectual process applied to understanding the social conditions which surrounded him. It is well known that the author was born and brought up within a family which showed acute social contrasts: a coalminer father and a lower middle-class mother who was led by her social ambitions to educate the children with a view to finding a way out of the limitations of the working classes. In the course of his life Lawrence learnt that he was not wholly accepted by the bourgeoisie and 
he realized that their rules did not enrich his experience at all, but rather impoverished it; Lawrence's biography is therefore marked by his alienation from all social groups and by a process of evolution which starts in the lower classes and comes back to them, after a period of identification with the middle layers of society (Wasson 290; Sanders 11-19; Martin 85; Holmes 1-15). Such an inner debate is reflected very often in the literary production of the author; the famous poem "The Saddest Day," published in the 1928 collection Pansies, for instance, reads:

\author{
O I was born low and inferior \\ but shining up beyond \\ I saw the whole superior \\ world shine like the promised land. \\ So up I started climbing \\ to join the folks on high \\ but when at last I got there \\ I had to sit and cry. \\ For I wasn't a bit superior \\ it was only affected and mean; \\ though the house had a fine interior \\ and the people were never in. \\ And so there came the saddest day \\ when I had to tell myself plain \\ the upper classes are just a fraud \\ you'd better get down again. \\ (Complete Poems 136) ${ }^{4}$
}

From the intellectual point of view there are two facets which shape Lawrence's attitude to social class in this period. On the one hand his artistic impulse led him to split his consciousness between the acceptance of his original community as a source of material for his writing, and the detachment needed to portray it with a literary purpose; the author was, in this sense, classless and ran the risk of being cut off from the realities of his world. On the other hand his awareness of class was also shaped by the evolution of his political thought. Before the First World War Lawrence could still feel a balance between "capital" and "labour": the first miners' union of the Midlands - the "Nottinghamshire and Derbyshire Miners' Association"-had just been founded, and the "Miners' National Union," established in 1889 , was starting to achieve the results of its vindications (Scheckner 436; Holderness 59-65); the liberal and harmonious environment favoured by this social reconciliation led Lawrence to regard the working classes positively, and to propose, in theory, a social revolution which, uninspired by political militancy, could free them of the barriers which hindered the development of human personality. It is interesting to notice how the conjunction of these personal and intellectual factors was responsible for the contradictions of the author's ideology and, at the same time, helped him to come to 
terms with his incompatible views: eventually he was to propose the need to overcome the pressures imposed by class differences as a merely circumstantial question when it was compared with a broad concept of the human being whose nature depends on a mutual collaboration with the aim of achieving a common welfare (Eagleton and Pierce 104; Martin 96). The author's prospects of a classless society are explicitly mentioned in the essay "Art and the Individual," written in March 1908; following Herbart's classification of human interests, he defines a sympathetic-social one as "the growing comprehension of the incorporation of the individual in the great social body whose interests are large beyond his personal feelings"; the individual is, therefore, "a unit working with others for a common welfare, like a cell in a complete body" (253). ${ }^{5}$ Such a cellular and monistic conception of the human being implies that no group or species within the social unity can achieve a perfection which does not result from a preconceived pattern.

It was in Croydon that Lawrence had to come to terms with his personal ambivalent situation for the first time: his belonging both to the working class and to the educated middle classes. And it was there and then that he first began to explore the gulfs between people in his literary production. Such an experiment seems to have invalidated the theoretical scheme he had produced in "Art and the Individual" and instigated in his thought a sense of isolation, compatible with his artistic aims. He could no longer believe that the working classes would make his plans become a reality; he noticed that they were surrounded by poverty and misery but observed his individualistic and materialistic aims. Later on, during the First World War, he would even give instructions in a letter to Bertrand Russell not to "believe in the people," but "let the working classes be working classes" (Collected Letters 352). Furthermore, Lawrence never saw the middle classes as the embodiment of his communal ideology; in the same letter they were accused of remaining "in this state of disintegration wherein each separate little ego is an independent principality by itself" (Collected Letters 360). Even though the letters belong to the year 1915 , it seems that already in 1909, a few months after having written "Art and the Individual," the short story "A Lesson on a Tortoise" reflects in embryo the intellectual process which would lead the author to reject his theoretical plans, feel betrayed by both classes and realize his isolation in the social spectrum.

It is true that the description of each group of pupils in the story includes both positive and negative overtones, but reading between the lines one can notice the initial preference of the narrator for the students related to the "Actors' Orphanage Fund"-the symbolic representative of the middle classes in the microcosm of his class: he has chosen Segar, a member of this group, as monitor and his first reaction on discovering the theft is to accuse the "Gordon" boys, symbolically associated with the lower layer. The confrontation between the latter group and the teacher may reveal the uneasiness and guilt of the author himself when facing the possibility of betraying a part of his real social origins; the narrator seems to be justifying himself-perhaps as Lawrence would have done in the same situation-when he realizes that his charges may lack a real ground. Nevertheless he insists on his weariness for having had to excuse the defensive behaviour of the working classes: "I'm always excusing you, letting you off!" (19), he says when one of the "Gordon" boys protests the incoherence of the accusation. The outcome of his inquiry is a demonstration of the dishonesty of the middle classes. The narrator's crisis is, therefore, 
caused by the collapse of his desire to believe in the fine rather than the sordid, and by his awareness that he belongs simultaneoulsy to both groups and to neither.

To sum up, the chronological relationship between the story and "Art and the Individual" helps to understand that the ideological substratum provided by the latter had already been shattered when the former was written. But it also helps to value the intellectual appraisal of the communal instincts of the human being which lie behind the essay as the element which, together with the personal circumstances of the author, prompts the rejection of both social groups in the thought of D. H. Lawrence.

\section{Notes}

1. According to Sagar the story had been written in November 1908 and revised in January of the following year (8-10). Worthen, however, proposes the later date of December 1909 on the evidence that the type of paper of the manuscript is identical with the one Lawrence was using that year (Introduction XXV). The story remained unpublished throughout the author's life until 1968, when Roberts and Moore included it in Phoenix II; it has recently been edited by Worthen for Cambridge University Press in the collection Love Among the Haystacks and Other Stories, where the quotations in the article come from.

2. "The routine of school life was to Lawrence abhorrent ... he was intolerant of authority. While imposing his own rule upon his pupils, he rebelled against any such process as being even suggested to himself" (Nehls 84; see Moore 122-25).

3. Lawrence, in a letter to Helen Corke, compared the boys from the "Gordon Home" to poorer and less-nourished boys who, however, "maintained a caste superiority which isolated the unfortunates" (Corke 153). This gives a definite portrait of the social reality the author had to face in Croydon and the actual organization of the class which worked as inspiration for the short story.

4. See also, in the same collection, "Red Herring," "Climbing Up," "A Rise in the World" and "Have Done with It." Lawrence would also refer to this situation in the "Autobiographical Sketch" of 1928, which curiously had the title "Which Class I Belong to" in previous revisions; there he writes: "I cannot make my transfer from my own class into the middle class. I cannot, not for anything in the world, forfeit my passional consciousness and my old blood-affinity with my fellow-men, and the animals and the land, for that other thin, spurious mental conceit which is all that is left of the mental consciousness, once it has made itself exclusive" (Phoenix II 300).

5. Ebbatson has studied the influence of some evolutionist thinkers of the late nineteenth century in the development of this definition of social structure. Besides J. Herbart's The Science of Education and the Aesthetic Revelation of the World he also acknowledges the role played by E. Haecknell's The Riddle of the Universe (1864) and H. Spencer's First Principles (1862) (35-37). It is interesting to quote the following words of the latter author as a good example of what Lawrence meant in "Art and the Individual": "From the lowest living forms upward, the degree of development is marked by the degree in which the several parts constitute a cooperative assemblage-are integrated into a group of organs that live for and by one another" (Ebbatson 42). 


\section{Works Cited}

Chambers, J. D. H. Lawrence: A Personal Record. London: Jonathan Cape, 1932.

Corke, H. In Our Infancy. Cambridge: Cambridge UP, 1975.

Cushman, K. "The young Lawrence and the short story," Modern British Literature 3 (1978): 101 12.

Ebbatson, R. Lawrence and the Nature Tradition. Hassock: The Harvester Press, 1980.

Eagleton, M. and D. Pierce. Attitudes to Class in the English Novel. London: Thames and Hudson, 1979.

Harris, J. H. The Short Fiction of D. H. Lawrence. New Brunswick: Rutgers UP, 1984.

Hobsbaum, P. A Reader's Guide to D. H. Lawrence. London: Thames and Hudson, 1981.

Holderness, G. D. H. Lawrence: History, Ideology and Fiction. Humanities Press, 1982.

Holmes, C. "Lawrence's social origins." D. H. Lawrence: New Studies. Ed. C. Heywood. London: Macmillan, 1987. 1-15.

Hueffer, F. M. Foreword. The English Review of Short Stories. Ed. H. Shipp. London: Samson, Low and Marston, 1932. 1-16.

Lawrence, D. H. "Art and the individual." 1908. Young Lorenzo: The Early Life of D. H.

Lawrence. By A. Clarke (Lawrence) and G. S. Gelder. New York: Russell, 1931. 249-68. . "A Lesson on a tortoise." 1909. Love Among the Haystacks and Other Stories. Ed. J.

Worthen. Cambridge: Cambridge UP, 1987. 16-20.

. The Collected Letters of D. H. Lawrence. Ed. H. T. Moore. London: Heinemann, 1962. . The Complete Poems of D. H. Lawrence. Ed. V. Sola Pinto and W. Roberts. London:

Heinemann, 1964.

.Phoenix II: Uncollected, Unpublished and Other Prose Works by D. H. Lawrence. Ed. W.

Roberts and H. T. Moore. London: Heinemann, 1968. The Letters of D. H. Lawrence. Ed. J. T. Boulton. Cambridge: Cambridge UP, 1979.

Leavis, F. R. D. H. Lawrence: Novelist. London: Chatto and Windus, 1955.

Martin, G. "D. H. Lawrence and Class." The Uses of Fiction. Ed. D. Jefferson and G. Martin. Milton Keynes: Open University Press, 1982. 83-97.

Moore, H. T. The Priest of Love. Harmondsworth: Penguin, 1980.

Nehls, E. D. H. Lawrence: A Composite Biography. U of Wisconsin P, 1957.

Pinion, F. B. A D. H. Lawrence Companion. London: MacMillan, 1978.

Sagar, K. D. H. Lawrence: A Calendar of his Works. Manchester: Manchester UP, 1979.

Sanders, S. "Introduction: Literary Consciousness and Social Reality." D. H. Lawrence: The World of the Major Novels. London: Vision, 1973. 11-19.

Scheckner, P. "Class Consciousness in the Works of D. H. Lawrence: A New Reading." Midwest Quarterly 25.4 (1984): 434-49.

Wasson, R. "Class and the Vicissitudes of the Male Body in Works by D. H. Lawrence." D. $H$. Lawrence Review 14.3 (1981): 289-305.

Worthen, J. Introduction. Love Among the Haystacks and Other Stories. By D. H. Lawrence. Cambridge: Cambridge UP, 1987. XXI-XLIX.

D. H.Lawrence: The Early Years, 1885-1912. Cambridge: Cambridge UP, 1991.

Young, K. D. H. Lawrence, London: Lomgman, 1952. 